Куницький С. О., к.т.н. (Національний університет водного господарства та природокористування, м. Рівне)

\title{
ОЦІНКА ЯКОСТІ ВОДИ ПІДЗЕМНИХ ДЖЕРЕЛ ВОДОПОСТАЧАННЯ РІВНЕНСЬКОÏ ОБЛАСТІ
}

Проаналізовано показники якості артезіанської води з свердловин, розташованих в різних населених пунктах Рівненщини; окреслено тенденції якісного стану підземних артезіанських горизонтів; обґрунтовано рекомендації щодо водопідготовки залізовмісних вод. Наведено фізико-хімічний склад води з підземних горизонтів різних населених пунктів Рівненщини.

Ключові слова: якість води, вміст заліза, знезалізнення.

Вступ. В умовах інтенсивного розвитку всіх галузей економіки, погіршення якості джерел водопостачання й зростаючих вимог до якості вод великого значення набуває виробництво технічної і питної води.

Аналіз світових тенденцій щодо забезпечення якості води показує, що на європейському континенті існує диференціювання по якісній воді не лише по країнах, а й по містах та селах. В Австрії, Німеччині, Польщі, Чехії, Словенії, Швейцарії, Великобританії, Франції, Нідерландах, Бельгії, Люксембурзі, Ліхтенштейні тощо якість водопровідної води є придатною до споживання 3-під крану. Натомість у країнах Східної Європи доволі часто вже питна вода може отримувати вторинне забруднення через несприятливий стан водопровідних мереж [1].

Стан водних ресурсів та водозабезпечення населення України залишається однією з головних актуальних загроз національної безпеки України в екологічній сфері, яка в умовах економічної та політичної трансформації, військового конфлікту та в умовах перерозподілу вологи набуває нових аспектів та гостроти. Особливу актуальність набувають питання адаптації управління водними ресурсами в умовах змін клімату.

Територія України забезпечена водними ресурсами нерівномірно й деякі регіони вкрай потерпають від дефіциту цього ресурсу. В регіональному співвідношенні поверхневу воду споживає населення більшої частини території України (близько 70\%). Проте, поверхневі 
води найчастіше містять завислі речовини, характеризуються значною забарвленістю, мають специфічний запах та присмак. Такі домішки погіршують фізико-хімічні параметри води й потребують вилучення перед транспортуванням у водопровідну мережу [1; 2]. Очищена вода повинна відповідати нормативним вимогам до їі складу [3].

У невеликих населених пунктах використовують ґрунтові та артезіанські води. Ґрунтові води добуваються з колодязів та неглибоких свердловин, здебільшого до 40-50 м. Досить часто містять пестициди й гербіциди, іони важких металів, ПАР та інші небезпечні речовини.

Артезіанські води нашої країни часто характеризуються підвищеними концентраціями заліза - приблизно в 50\% підземних водозаборів спостерігається підвищена концентрація заліза. I ця цифра має тенденцію до зростання. Надмірні концентрації заліза надають воді буруватого забарвлення, неприємного металічного присмаку, викликає заростання водопровідних труб та арматури $[1 ; 4 ; 6]$. Хоча залізо виконує важливі функції в організмі людини (основна з них перенесення кисню), проте, надмірна його концентрація в організмі людини призводить до руйнування клітин печінки.

Використання підземних вод є пріорітетнішим, оскільки вони менш каламутні, хоча часто мають значний вміст заліза, марганцю, вуглекислоти та розчинені гази [5-7].

Постановка мети і задач дослідження. Головною метою статті $€$ оцінити стан та якість артезіанських вод в Рівненській області.

Задачі статті:

- оцінка методу підготовки води до вимог «Вода питна»;

- проаналізувати показники якості артезіанської води з свердловин, розташованих в різних населених пунктах Рівненщини;

- окреслити тенденції якісного стану підземних артезіанських горизонтів;

- обґрунтувати рекомендації щодо водопідготовки залізовмісних вод.

Вибір методу знезалізнення та його технологічних параметрів $є$ досить складною техніко-економічною задачею та залежить від хімічних властивостей води, продуктивності тощо [1; 2; 4 ].

Підземні води часто сильно мінералізовані. За ступенем мінералізації (за В. Вернадським) вони поділяються на: прісні (до 1 г/дм³); солонуваті (від 1 до 10 г/дм³); солоні (від 10 до 50 г/дм³); пі- 
дземні розсоли (понад 50 г/дм³) [2].

Більшість підземних вод надійно захищені від потрапляння в них забруднених поверхневих стоків. Їх кількість та якість меншою мірою, ніж поверхневі води, залежить від атмосферних опадів. Підземні води можуть займати значні території, мають переважно постійну температуру $\left(7 \ldots 13^{\circ} \mathrm{C}\right)$, можуть використовуватися для господарсько-питних потреб без очистки або достатньо простою очисткою, найчастіше від заліза та розчинених газів.

Існують методи знезалізнення: безреагентні, реагентні, катіонообмінні, біохімічні $[4 ; 6]$. Кожен із них має свої переваги й недоліки, але всі вони (за винятком іонообмінного) ґрунтуються на окисненні заліза II до заліза III, при чому відбувається перехід заліза в нерозчинну форму, яка затримується на фільтрах.

Метод катіонного обміну застосовують одночасно зі зм'якшенням води. Він полягає в обміні катіонів заліза, кальцію та магнію на катіони натрію та водню завдяки спеціальним засипкам фільтра. Крім того, згідно [2] з'єднання заліза отруюють катіони, зменшують затримувальну спроможність слабко основних аніонітів по аніонам сильних кислот на $15 . .20 \%$, ступінь сорбції заліза складає $90 . .95 \%$.

Біохімічний метод передбачає заселення на відповідному носії спеціальних залізобактерій з наступним фільтруванням на фільтрах. Для біологічного очищення частіше всього застосовують сухі фільтри, споруди двоступеневої фільтрації. Позитивний вплив на процес очищення мікроорганізмів $\epsilon$, але підрахувати приріст залізобактерій неможливо і споруди, що запроектовані за цим принципом, інколи важкі для контролю.

Безреагентні та реагентні методи називають ще фізикохімічними методами, які передбачають введення окислювачів заліза. В першому методі цим окислювачем $є$ кисень повітря, а в другому у воду вводять розчини хімічних окислювачів. Завданням методів $\epsilon$ переведення розчинних форм заліза в малорозчинні форми $\mathrm{Fe}(\mathrm{OH})_{3}$, чого досягають окисленням із наступним його осадженням або затриманням у товщі фільтруючої засипки [2-4].

В результаті окислення 1 мг гідрокарбонату заліза утворюється 1,6 мг вільної вугільної кислоти, загальна лужність води знижується на 0,043 мг-екв/дм³ ${ }^{3}$ можливе зменшення $\mathrm{pH}$, сповільнюється окислення й гідроліз заліза.

У перерахованих способах залізо переводиться в гідроксид заліза, при цьому може виділятися велика кількість вуглекислого газу. Окислення заліза може проводитись шляхом глибокої та спрощеної 
аерації.

При глибокій аерації процес окислення заліза починається у аераційних пристроях із значним подрібненням потоку води або повітря для створення найбільшого контакту з повітрям (наприклад, градирнях) і закінчується в проміжних місткостях, резервуарах, відстійниках, де утворюються пластівці гідроксиду заліза. На фільтрах проходить затримка сформованих пластівців гідроксиду заліза за тими самими законами, що і на швидких фільтрах при проясненні води, але додається сорбція непрореагованих іонів двовалентного заліза і кисню [6].

В Україні найпоширеніші безреагентні аераційні методи знезалізнення води, які передбачають насичення киснем повітря води, 3 метою отримання закисного заліза, та подальшого його затримання в зернистій засипці фільтрів. Тип фільтруючої засипки та їі параметри суттєво впливають на ефективність знезалізнення води.

Результати дослідження. У виробничих умовах відбір проб проводиться безпосередньо 3 артезіанської свердловини, перед блоком аерації. Протягом 2013-2017 рр. були відібрані проби води та проведені дослідження фізико-хімічного складу природних вод зі свердловин у Рівненській області. Склад води відрізнявся за рядом показників, зокрема за вмістом заліза, сірководню та розчиненої вуглекислоти.

Найбільш доцільно й економічно вигідно застосувати безреагентні аераційні методи знезалізнення води з одночасною дегазацією розчинених газів та фільтрування через швидкі фільтри.

Зростання кількості населення та ступеню благоустрою будинків, збільшення обсягів виробництва, а також задовільна якість фільтрату (за кольором і присмаком) та незадовільна робота станції (недотримання розрахункових параметрів роботи, недостатня пропускна здатність, винесення пінополістиролу з фільтра в каналізацію, а також ряд інших причин) стали визначальними при реконструкції діючої станції знезалізнення смт Гоща Рівненської області. Реконструкція станції була здійснена в 2011 році (І черга). Згідно проекту станцію було обладнано 3-ма фільтрів діаметром 1400 мм і 1-м діаметром 1200 мм. Для окислення заліза встановлено два повітрявідділювачі діаметром 630 мм. У 2016 році проведено реконструкцію станції (II черга), - пінополістирольного фільтра діаметром 2500 мм шляхом заміни фільтруючої засипки та конструкції підтримуючих шарів.

22 березня 2017 року було визначено показники якості артезі- 
анської води зі свердловини глибиною 67 м Гощанського водоочисного комплексу (смт Гоща, Рівненська обл. (табл. 1).

Таблиця 1

Показники якості артезіанської води смт Гоща

\begin{tabular}{|c|c|c|c|}
\hline $\begin{array}{c}\text { № } \\
3 / \Pi\end{array}$ & Показники & $\begin{array}{c}\text { Одиниці } \\
\text { виміру }\end{array}$ & Значення \\
\hline 1 & Запах при $20^{\circ} \mathrm{C}$ & бал & 3...5 (сірководень) \\
\hline 2 & $\mathrm{pH}$ & -- & $6,96 \ldots 7,1$ \\
\hline 3 & Залізо загальне: & мг/дм ${ }^{3}$ & $1,66 \ldots 3,55$ \\
\hline 4 & Залізо двовалентне & $\mathrm{Mr} / \mathrm{gm}^{3}$ & $0,06 \ldots 0,12$ \\
\hline 5 & Залізо тривалентне & мг/дм³ & $1,6 \ldots 3,43$ \\
\hline 6 & Жорсткість загальна & моль/м³ & 6,9 \\
\hline 7 & Кальцій & моль $/ \mathrm{M}^{3}$ & 5,2 \\
\hline 8 & Магній & моль/м³ & 1,7 \\
\hline 9 & Сульфати & мг/дм³ & $9,4 \ldots 16,4$ \\
\hline 10 & Хлориди & мг/дм³ & $7,0 \ldots 10,0$ \\
\hline 11 & Аміак & мг/дм ${ }^{3}$ & $0,37 \ldots 0,96$ \\
\hline 12 & Нітрати & мг/дм ${ }^{3}$ & $<0,1$ \\
\hline 13 & Марганець & мг/дм³ & $0,15 \ldots 0,16$ \\
\hline 14 & Вільна вуглекислота & мг/дм & $52,4 \ldots 76,7$ \\
\hline 15 & Лужність & моль/м³ & 6,9 \\
\hline 16 & Калій+натрій & мг/дм³ & $12,0 \ldots 13,5$ \\
\hline 17 & Мінералізація & мг/дм ${ }^{3}$ & $368 \ldots 372$ \\
\hline
\end{tabular}

Якість води не відповідає вимогам до питної води за концентраціями загального заліза, марганцю та запахом, що пов'язано з наявністю у воді сірководню. Таким чином, постає питання щодо поліпшення якісного складу води. 
Наступний етап дослідження складу підземних вод проводилося у смт Рокитне Рівненської області. Глибина свердловини становила 34 м. Результати представлені в табл. 2.

Таблиця 2

Показники якості артезіанської води смт Рокитне

\begin{tabular}{|c|c|c|c|c|}
\hline № $3 / п$ & Показники & $\begin{array}{l}\text { Одиниці } \\
\text { виміру }\end{array}$ & Значення & $\begin{array}{c}\text { ДСанПін } \\
2.2 .4- \\
171-10 \\
\text { для води } \\
\text { питної } \\
\text { водо- } \\
\text { провідної }\end{array}$ \\
\hline 1 & Запах при $20^{\circ} \mathrm{C}$ & бал & $\begin{array}{c}\mathbf{3 . . . 3 , 5} \\
\text { (сірководень) }\end{array}$ & $\leq 2$ \\
\hline 2 & $\mathrm{pH}$ & -- & 6,0 & $6,5-8,5$ \\
\hline 3 & Залізо загальне: & мг/дм ${ }^{3}$ & 17,0 & $\leq 0,2$ \\
\hline 4 & Залізо двовалентне & $\mathrm{Mr} / \mathrm{дM}^{3}$ & 6,4 & $\leq 0,1$ \\
\hline 5 & Залізо тривалентне & $\mathrm{Mr} / \mathrm{дм}^{3}$ & 10,6 & $\leq 0,1$ \\
\hline 6 & Жорсткість загальна & моль/м & 2,5 & $\leq 7,0$ \\
\hline 7 & Кальцій & моль/м ${ }^{3}$ & 1,8 & $1,25-3,74$ \\
\hline 8 & Магній & моль/м & 0,7 & $0,82-4,11$ \\
\hline 9 & Сульфати & мг/дм ${ }^{3}$ & 51,2 & $\leq 250,0$ \\
\hline 10 & Хлориди & $\mathrm{Mr} / \mathrm{дм}^{3}$ & 23,0 & $\leq 250,0$ \\
\hline 11 & Аміак & $\mathrm{Mr} / \mathrm{дM}^{3}$ & 1,41 & $\leq 0,5$ \\
\hline 12 & Нітрати & мг/дм ${ }^{3}$ & $<0,45$ & $\leq 50,0$ \\
\hline 13 & Марганець & $\mathrm{Mr} / \mathrm{дм}^{3}$ & 0,77 & $\leq 0,05$ \\
\hline 14 & Вільна вуглекислота & мг/дм ${ }^{3}$ & 110,0 & \\
\hline 15 & Лужність & моль $/ \mathrm{M}^{3}$ & 1,0 & $0,5-6.5$ \\
\hline 16 & Калій+натрій & мг/дм ${ }^{3}$ & 1,8 & $1,25-3,74$ \\
\hline 17 & Мінералізація & $\mathrm{Mr} / \mathrm{дM}^{3}$ & 180,0 & $<1000$ \\
\hline
\end{tabular}

Згідно нормативних показників якість води не відповідає вимогам до питної води за концентраціями загального заліза, аміаку та марганцю. Неприємний запах води пов'язаний з наявністю розчиненого сірководню. Тому постає питання щодо поліпшення якісного складу води.

Система водопостачання м. Рівне та прилеглих населених пунктів включає водозабірні свердловини, які здійснюють водозабір підземної води з верхньокрейдяного, валдайського та горбашівського водоносних горизонтів, обладнаних насосами типу ЕЦВ. В табл. 3 на- 
ведено перелік артезіанських свердловин на водозабірних майданчиках для водопостачання м. Рівне та прилеглих населених пунктів.

Таблиця 3

Артезіанські водозабірні свердловини для

водопостачання м. Рівне та прилеглих населених пунктів

\begin{tabular}{|l|c|}
\hline \multicolumn{1}{|c|}{ Назва водозабору } & \multicolumn{1}{|c|}{$\begin{array}{c}\text { Кількість } \\
\text { свердловин }\end{array}$} \\
\hline майданчик № 1 по вул. Ст. Бандери, 2 & 10 \\
\hline $\begin{array}{l}\text { майданчик № 3 по вул. Чорновола, 89 } \\
\text { «Новий Двір» }\end{array}$ & 23 \\
\hline майданчик № 4 по вул. Ол. Олеся & 7 \\
\hline майданчик «Боярка» & 6 \\
\hline майданчик «Новомильськ» & 12 \\
\hline майданчик «Бабин» & 6 \\
\hline майданчик «Горбаків» & 30 \\
\hline вул. Київська & 2 \\
\hline смт Квасилів & 3 \\
\hline вул. Курчатова & 3 \\
\hline $\begin{array}{l}\text { вул. Млинівська, Чернишова, } \\
\text { ВАТ «РЗТА» (резервні свердловини) }\end{array}$ & 5 \\
\hline Всього: & 107 \\
\hline
\end{tabular}

Якість води у свердловинах відрізняється за фізико-хімічними показниками й досить суттєво залежить від порід, які оточують водоносний горизонт. Сумарна продуктивність свердловин водозабо-

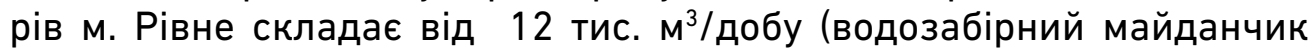
«Новомильськ» в с. Новомильськ Здолбунівського р-ну) до 50000 м³/добу (водозабірний майданчик «Горбаків» розташований в с. Горбаків Гощанського району). Глибини свердловин змінюються в діапазоні від 55 до 700 м (наприклад сведловини на водозабірному майданчику № 4 «Боярка»). Підземна вода видобувається із свердловини глибиною від за допомогою глибинних насосів типу ЕЦВ.

Розглянемо водозабірний майданчик №3, «Новий Двір» вул. Чорновола, 89) розташований в південній частині міста Рівне та прилеглої до неї території. Потужність водозабору, згідно затвер-

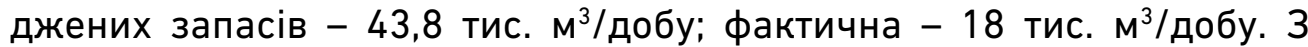
свердловини вода системою трубопроводів подається на станцію знезалізнення, звідки після очищення самопливом поступає в РЧВ, де знезаражується гіпохлоритом натрію (від хлораторної). Далі насосними станціями вода перекачується в водопровідну мережу.

Результати хімічного аналізу підземної та очищеної води зі све- 
рдловин водозабірного майданчику № 3, «Новий Двір», які проводилися у вересні 2018 року, представлені в табл. 4.

Таблиця 4

Результати хімічного аналізу проб артезіанської води водозабірного майданчику № 3, «Новий Двір», м. Рівне

\begin{tabular}{|c|c|c|}
\hline Показники & Одиниці & $\begin{array}{c}\text { Підземна зі } \\
\text { свердловини }\end{array}$ \\
\hline $\mathrm{pH}$ & од. $\mathrm{pH}$ & 7,35 \\
\hline Лужність & мг-екв/дм³ & 8,1 \\
\hline Жорсткість & мг-екв/дм³ & 7,3 \\
\hline Залізо загальне & мг/дм ${ }^{3}$ & 2,17 \\
\hline Залізо тривалентне & мг/дм ${ }^{3}$ & 0,85 \\
\hline Залізо двовалентне & мг/дм ${ }^{3}$ & 1,32 \\
\hline Окисність перманганатна & $\mathrm{мгO}_{2} /$ дм $^{3}$ & 0,736 \\
\hline Сухий залишок & мг/дм ${ }^{3}$ & 510 \\
\hline
\end{tabular}

Води багатьох підземних водоносних горизонтів Рівненщини мають підвищений вміст заліза, який коливається від 0,5..25 мг/дм³. Вміст загального заліза в артезіанській воді зі свердловин населених пунктів Рівненської області наступний: м. Корець - 5,1...5,4; м. Рокитне - 6,0...24,5; с. Селище, Сарненського району - 3,0...6,0; м. Рудня, Дубровицького району - 1,75...4,7; с. Ясногорка, Сарненського району - 3,25...4,5; с. Терентів, с. Франівка Гощанського району $-1,0 \ldots 4,2$ мг/дм³

Таким чином, якісний склад води з підземних горизонтів потребує попередньої підготовки на станціях знезалізнення води й дегазації розчинених газів. Вцілому якість води є задовільною, за виключенням загального заліза, сірководню та марганцю.

1. Дослідження процесу знезалізнення підземної води на зернистих фільтpax з підвищеною крупністю гранул / В. О. Орлов, С. Ю. Мартинов, С. О. Куницький, М. М. Меддур. Вісник НУВГП : зб. наук. праць. Рівне : НУВГП, 2012. Вип. 4(60). 268 с. 2. Water quality produced by polystyrene granules as a media filter on rapid filters / J. M. Schöntag, B. S. Pizzolatti, V. H. Jangada, F. H. de Souza, M. L. Sens. Journal of Water Process Engineering. 2015. Vol. 5. P. 118-126. 3. ДСанПіН 2.2.4-171-10. Гігієнічні вимоги до води питної, призначеної для споживання людиною. 12.05.2010 (Нормативні директивні правові документи). 4. Очищення природної води на пінополістирольних фільтрах / В. О. Орлов, С. Ю. Мартинов, А. М. Орлова, В. О. Зощук, Н. Л. Мінаєва, С. О. Куницький та ін. : монографія ; під заг. ред. В. О. Орлова. Рівне : НУВГП, 2012. 172 с. 5. Żurek A. Environmental flow as an area of potential conflict between the role of groundwater in the supply and its environmental function. Acta Scientiarum Polonorum. 2014. Issue 13 (4). Р. 301-314. 6. Хоружий П. Д., Хомутецька Т. П., Хоружий В. П. Ресурсозберігаючі технології водопоста- 
чання. Київ, Аграрна думка, 2008. 269 с. 7. Ютилов М. МЖФ - Марганец Железо Фильтр - Новый фильтрующий материал для обезжелезывания. Вода и водоочистные технологии. 2011. № 2(56). С. 38-43.

\section{REFERENCES:}

1. Doslidzhennia protsesu znezaliznennia pidzemnoi vody na zernystykh filtrakh z pidvyshchenoiu krupnistiu hranul / V. O. Orlov, S. Yu. Martynov, S. O. Kunytskyi, M. M. Meddur. Visnyk NUVHP : zb. nauk. prats. Rivne : NUVHP, 2012. Vyp. 4(60). 268 s. 2. Water quality produced by polystyrene granules as a media filter on rapid filters / J. M. Schöntag, B. S. Pizzolatti, V. H. Jangada, F. H. de Souza, M. L. Sens. Journal of Water Process Engineering. 2015. Vol. 5. P. 118-126. 3. DSanPiN 2.2.4-171-10. Hihiienichni vymohy do vody pytnoi, pryznachenoi dlia spozhyvannia liudynoiu. 12.05.2010 (Normatyvni dyrektyvni pravovi dokumenty). 4. Ochyshchennia pryrodnoi vody na pinopolistyrolnykh filtrakh / V. O. Orlov, S. Yu. Martynov, A. M. Orlova, V. O. Zoshchuk, N. L. Minaieva, S. O. Kunytskyi ta in. : monohrafiia ; pid zah. red. V. O. Orlova. Rivne: NUVHP, 2012. 172 s. 5. Żurek A. Environmental flow as an area of potential conflict between the role of groundwater in the supply and its environmental function. Acta Scientiarum Polonorum. 2014. Issue 13 (4). P. 301-314. 6. Khoruzhyi P. D., Khomutetska T. P., Khoruzhyi V. P. Resursozberihaiuchi tekhnolohii vodopostachannia. Kyiv, Ahrarna dumka, 2008. 269 s. 7. Yutilov M. MZhF - Marhanets Zhelezo Filtr - Novyi filtruiushchii material dlia obezzhelezyvaniia. Voda $i$ vodoochistnye tekhnolohii. 2011. № 2(56). S. 38-43.

Kunytskyi S. O., Candidate of Engineering (Ph.D.) (National University of Water and Environmental Engineering, Rivne)

\section{WATER QUALITY ASSESSMENT OF UNDERGROUND SOURCES OF WATER SUPPLY OF THE RIVNE REGION}

The state of water resources and water supply of the population of Ukraine remains one of the major pressing threats to the national security of Ukraine in the ecological sphere, which in the conditions of economic and political transformation, military conflict and in the conditions of moisture redistribution acquires new aspects and acuteness. The issue of adaptation of water management in the face of climate change is of particular relevance.

The territory of Ukraine is provided with irregular water resources and some regions are extremely affected by the scarcity of this resource. Artesian waters of Ukraine are often characterized by high concentrations of iron - in about $50 \%$ of underground water intakes there is a high concentration of iron. And that number tends to increase. Excessive concentrations of iron give the water a brownish 
color, an unpleasant metallic taste, causes overgrown water pipes and fittings. In small towns, groundwater and artesian water are used. Groundwater is extracted from wells and shallow wells, mostly up to 40-50 m. They often contain pesticides and herbicides, heavy metal ions, surfactants and other dangerous substances. The water quality in the wells of Rivne region differs in physicochemical parameters and depends significantly on the rocks that surround the aquifer.

For water treatment of groundwater use non-reagent, reagent, cationexchange, biochemical methods. Each has its own peculiarities of use. It is most expedient and economically advantageous to apply nonreagent aeration methods of water desalination with simultaneous degassing of dissolved gases and filtration through fast filters. During 2013-2017 water samples were taken and studies of the physicochemical composition of natural water from wells in Rivne region were conducted. The composition of water varied in a number of indicators, in particular the content of iron, hydrogen sulfide and dissolved carbon dioxide.

The quality of artesian water from wells located in different settlements of Rivne region is analyzed; the trends of the qualitative state of underground artesian horizons are outlined;

recommendations for water treatment of iron-containing water are substantiated. The physicochemical composition of water from underground horizons of different settlements of Rivne region is given.

Keywords: water quality, iron content, iron removal.

Куницкий С. О., к.т.н. (Национальный университет водного хозяйства и природопользования, г. Ровно)

\section{ОЦЕНКА КАЧЕСТВА ВОДЫ ПОДЗЕМНЫХ ИСТОЧНИКОВ ВОДОСНАБЖЕНИЯ РОВЕНСКОЙ ОБЛАСТИ}

Проанализированы показатели качества артезианской воды из скважин, расположенных в разных населенных пунктах Ровенской области; обозначены тенденции качественного состояния подземных артезианских горизонтов; обоснованы рекомендации по водоподготовке железосодержащих вод. Приведены физикохимический состав воды из подземных горизонтов различных населенных пунктов Ровенской области.

Ключевые слова: качество воды, содержание железа, обезжелезывания. 